\title{
鐙骨筋の収縮による伝音能率低下
}

\author{
村田 清高* ・斎藤 春雄**

\section{The Role of Stapedius Muscle in Sound Conduction}

\author{
Kiyotaka Murata, \& Haruo Saito. \\ (Kyoto. Univ.)
}

\begin{abstract}
Misdirection to the stapedius muscle after facial palsy was studied in an attempt to determine the effect of muscle contraction upon sound transmission. Maximum hearing loss of $40 \mathrm{~dB}$ at low frequencies was attained during voluntary contraction concomitant with eye closure and whistling.

The hearing loss resulted from stapedius muscle contraction, as this phenomenon disappeared after surgical amputation of the stapedius tendon.
\end{abstract}

\section{はじめに}

鐙骨筋の収縮によっておてる聴力低下は, 鐙骨筋の音響性反射収縮による内耳の保護作用に関連 する重要な問題である. 音響性反射収縮は, 持続時間が短く, 聴力に与える影響をヒトで直接測定 することが難しく，乙れにかわって，てれまで, 多数の動物実験 (Wever, Békésy 等) によっ て，鐙骨筋収縮による伝音能率の低下が測定された。それによると，主に低音域で， $5 \sim 15 \mathrm{~dB} の$ 聴力低下が報告されている(1)34) 6) 8) 9) 10) 11) 12) 14) 15) 21) 23) 25) 28) 29) 30).

しかし，ヒトに関する測定は少ない．乙れまで，ヒトに関する報告をみると，先天的に，耳内筋 の随意的収縮が可能な患者について, 測定したものが多い $\left(\mathrm{Smith}^{22)}, \mathrm{Reger}^{19)}\right.$, 角 ${ }^{24)}, \mathrm{Pichler}^{18)}$, 中村 ${ }^{13)}$ ). 乙の場合, 鼓膜張筋, 鐙骨筋のいずれの収縮によるものであるか定かでない. 一般に, 鼓膜張筋の作用が, 鐙骨筋のそれより強いと考えられ, 低音域で, $30 \sim 40 \mathrm{~dB}$ の聴力低下が報告さ れている，鐙骨筋の収縮による聴力低下は，5１5dB で，鐙骨筋収縮による内耳の保護作用は，ほ とんどないというのが, これまでの定説である5.

今回，著者らは，ヒトで鐙骨筋の収縮によっておてる聴力低下を測定した貴重な症例を経験し た. これは, 顔面神経麻盘の回復過程におてる神経の misdirection の現象が, 鐙骨筋におてった あのを利用したあのである. 本論文では, 顔面神経麻痺後の痤卛症と, それに伴う耳鳴 および聴力 低下を主訴とする症例で，低音域に，40dB の域值上昇を認めた症例を中心に述べる．乙の主目的 は，鐙骨筋収縮による聴力䦭值の上昇の值の意義を検討するととである，乙の值は，乙れまで動物 
およびヒトで報告された值より，はるかに大きい，本症例は，鐙骨筋単独収縮によっておてる聴力 低下の最大值が, $40 \mathrm{~dB}$ に達しうるととを直接測定した初めての貴重な報告である.

症

48才，女子，

主訴：右顔面病摹症, 右耳鳴, 右聴力低下

家族歴：特記すべきものなし

既往歴：昭和50年12月，虫垂切除術

現症：昭和51年12月29日, 右耳介後部疼痛を 訴光，翌年 1 月 1 日，右顔面神経林瘦に気ずい た（図 1 )。昭和52年 1 月 4 日，右耳介，へ ルペス様湿疹を生じた（帯状疱疹の補体絬合 抗体価は，1月12日32倍，1月26日16倍であっ た).

このとき，右耳鳴なく，眩莗もなかったが， hyperacusis を認めた。 NETは, 患側の閾 値上昇あるむ, scale out していない. 右顔面 神経麻痺の回復はおそく，1月26日，なお部分 的麻瘏の状態にあった。

治療としては，保存的に行われ，ビタミン製 剂, A T P, ナイクリン, ソルコーテフなどの 静脈内持続点滴を，昭和52年 1 月 12 日より， 2 月 4 日にかけて, 合計 6 回行っている. 2 月に 入り, 右耳鳴（ワーン, ワーン, ザク, ザクの 2 種類）を訴えた，麻瘏の回復はおそく，外見 上,ほぼ麻瘏が回復したのは, 昭和52年 4 月頃 である. 同年 7 月 27 日，右側に病的共同運動お よび痤攀を確認された（口輪および眼輪筋間）. 同年11月には，疲労に際して，右侧眼角部が吊 り上る感じがすると訴えている，同52年 12 月 28 日の受診時は，右閉眼時右口角挙上，口をとが らすと，眼輪筋が少し収縮し，「イー」では動 かなかった。 また，右閉眼，ロとがらしに際し て, 右耳鳴（ゴー, ゴー）を聞き, 聴力が時々 低下寸るといっている. 昭和 53 年 1 月 14 日の otoadmittance 測定で，口をとがらす，閉眼 に一致して，耳小骨筋反射を確認した（図 2 ). 同年 1 月 25 日に行った聴力検査の結果は，図 3 の如くである．昭和52年 1 月 12 日の聴力は正常 であるととが確認されている， $1 \mathrm{KHz} ， 2 \mathrm{KHz}$
例

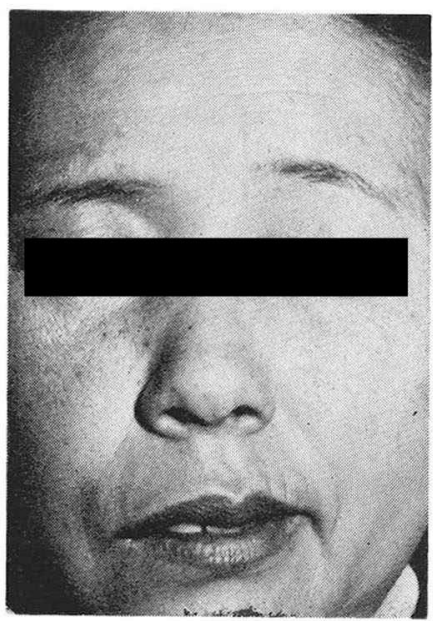

図 I，右顔面神経麻瘦の状態を示す，閉眼および 「イー」を指示している。

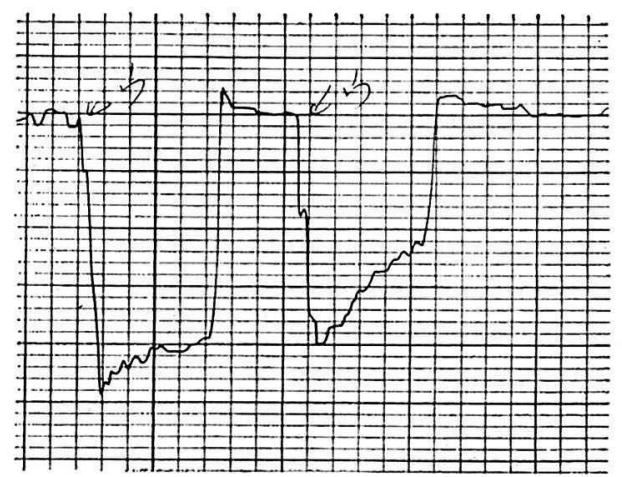

図 2. 口とがらしに際して確認された右耳小骨筋反射 を示す. 10 目盛が, $20 \mathrm{mmho}$ である.

で，口をとがらした時に，約 $40 \mathrm{~dB}$ の聴力低下 を認める．また， $250 \mathrm{~Hz}, 8 \mathrm{KHz}$ では，安静時 の方が聴力が低下している. 職業上, 子供に 「なーに」と問いただすとき，閉眼およびロ輪 筋に変化を (痤卛) おとしやすく，てのとき， 


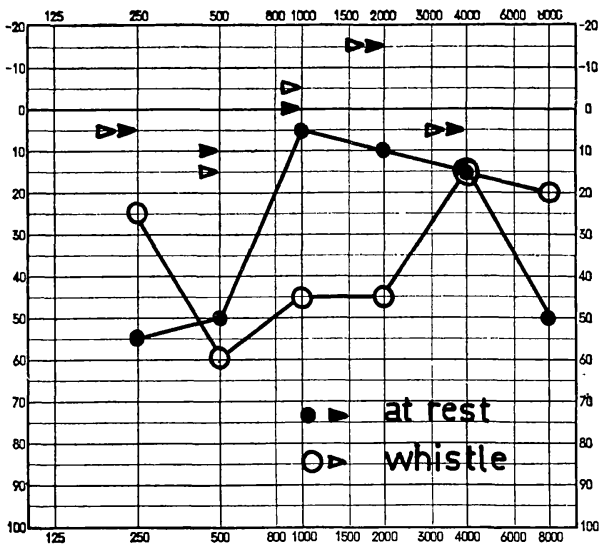

図 3. 右側標準純音聴力検査, 安静時と, 口をとがら せた時の気導

○, O-O), 骨導

(〉, \） の変化を示している. $1 \mathrm{KHz}, 2$

$\mathrm{KHz}$ で，口をとがらせた時に，約 $40 \mathrm{~dB}$ の聴力 低下を認める. $250 \mathrm{~Hz}, 8 \mathrm{KHz}$ では, 安静時 の方が聴力が低下している.

よけいに聴力が低下する之訴え，治療の必要性 を訴えた。昭和 53 年 3 月 30 日に，耳内切開によ り，鐙骨抢よび鐙骨筋を観察した，耳小骨の形 状は正常であった．閉眼，「ウー」によっても 手術顕微鏡下に，鐙骨筋の収縮を確認できなか った，鐙骨筋腱の切断によって，右耳鳴，口之 がらしに際しての著しい聴力低下は消失した。 との時のオージオグラムは，図 4 のでとくで，

考

鐙骨筋の収縮による伝音能率の低下は，とれ まで, 次のような方法によって, 鐙骨筋を収縮 させて，その時の聴力あるいは，蝸牛電位など の変化を測定して行われてきた. すなわち，(1) 反対側の耳に，強大音を与え，測定耳に，ほ之 んど同時におこる鐙骨筋の収縮，すなわち，鐙 骨筋の音響性反射収縮 ${ }^{13)}{ }^{29)}$ ，(2)鐙骨筋を電気的 亿刺激して ${ }^{15) 18)}$ ，直接乙れを収縮させる，(3)七 トで，先天的に鐙骨筋（これは確実な証拠がな (が）の随意的収縮が可能な症例の測定 ${ }^{192}{ }^{22)}$ 24) 27)，(4)鐙骨筋のみを収縮させる薬物の使用 ${ }^{4)}$, ) ${ }^{12)}$ ，(5)鐙骨筋に人工的に張力をかけ（例えば, おもり)，正円空管内の音圧の変化を測定 ${ }^{17) 14}$

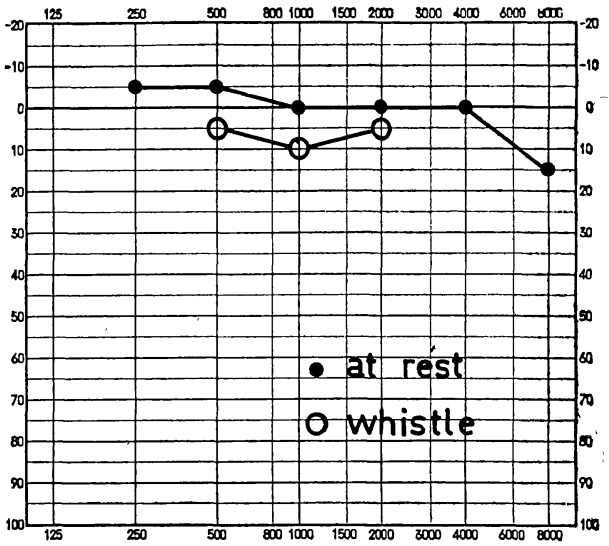

図 4 . 鐙骨筋腱切断後の標準純音聴力検査. 安静時と 口をとがらせた時に, 前図のような見るべき差 異を認めない。

安静時, 口をとがらせた時の聴力には, 術前の ような見るべき差を認めなかった。同53年 5 月 31日には，バス，子供の大声，大きな音などが 異常に大きく感じられると訴えた。同年 8 月 14 日 otoadmittance により，耳小骨筋反射の消 失を確認した。

患者は，鐙骨筋切断後，それまであったいら いらが消失し， hyperacusis の訴えがのとる も, 今回の治療結果に満足している.

\section{按}

25) 3)，等々の方法である.

この論文で報告する症例は, 顔面神経麻瘢の 回復過程でおこる神経の misdirection が, 鐙 骨筋におこり，顔面筋収縮とともにおこる鐙骨 筋の収縮を利用して，乙れが聴力低下におよぼ す值を測定したものである．この現象も，上述 の鐙骨筋収縮法の 1 つに，加えられてよいもの である。

さて，上述の方法によって，鐙骨筋を収縮さ せ，その時の聴力低下を測定した動物実験によ る報告は，多数あるが，図 5 に，乙の大きさを まとめた，横軸に周波数を，縦軸に，鐙骨筋の 収縮によっておこる聴力低下を，デシベルで示 


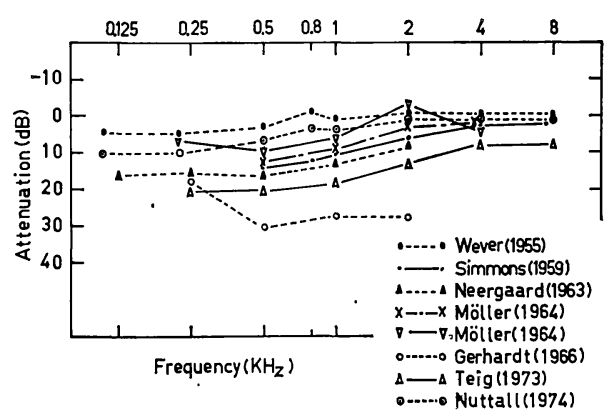

図 5 . 鐙骨筋収縮による伝音能率の低下. 各報告者の 測定条件（実験動物，鐙骨筋の収縮法，骨胞 の開閉) は，以下のごとくである. Wever \& Vernon（1955）一ネコ，音響性反射収縮，開 放骨胞，Simmons（1959）一ネコ，主に音響 性反射収縮, 閉鎖骨胞, Neergaard (1963) 七ト側頭骨標本, 鐙骨筋への張力負荷 $(6 \mathrm{~g})$. おそらく開放骨胞, Möller (1964) $(\times-\times)$

一家兔, 電気刺激, 開放骨胞, Möller (1964) $(\nabla-\nabla)$ 一ネコ，音響性反射収縮，開放骨胞 Gerhardt （1966）一モルモット，鐙骨筋へ張 力負荷おそらく開放骨胞, Teig (1973) 一ネ コ, 電気刺激, $5.17 \mathrm{~g}$ 負荷, 閉鎖骨胞. Nuttal （1974）一モルモット, 電気刺激, 開放骨胞.

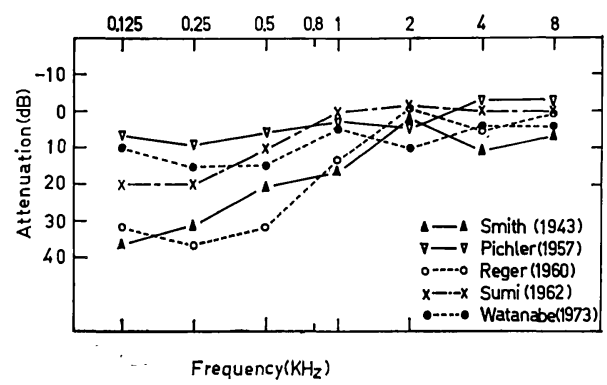

図 6.七ト耳小骨筋収縮による伝音能率の低下.

各報告者の測定条件は，次のごとくである.

Smith (1943) 一随意収縮可能な中耳耳小骨筋 収縮, 両耳の平均值, 鐙骨筋, 鼓膜張筋両方の 収縮か, 閉鎖中耳, Pichler（1957）－外耳道 皮膚電気刺激, 10耳の平均值, 両耳小骨筋か, Reger (1960) 一随意収縮. 両耳小骨筋力, 閉 鎖中耳, Sumi （1962）一随意収縮, 両耳小骨 筋収縮か, 渡辺（1973）一顔面神経麻瑥回復過 程の Misdirection.

してある，諸家の報告值は，低音部で，約 5〜 $15 \mathrm{~dB}$ の聴力低下にとどまっているのがわか る、わずかに Gerhardt がモルモットを使用し た実験で，30dB に達したという報告を，Teig
が $5.17 \mathrm{~g}$ 張力負荷により， $20 \mathrm{~dB}$ 低下をみたと 報告をしている． Neergaard のヒト側頭骨に よる測定む，生体でないので便宜上，この図に 含めた。

図 6 に，ヒト耳小骨筋収縮による聴力低下の 報告例をまとめた。とれによると，Smith22)， Reger ${ }^{19)}$ で， $250 \mathrm{~Hz}$ および $1 \mathrm{KHz}$ で，それぞ れ15ないし30dB，および15ないし $35 \mathrm{~dB}$ の聴力 低下をみている. 但し, $125 \mathrm{~Hz} て ゙$, Smith は, $40 \mathrm{~dB}$ 低下を報告している. これらの症例は, 収縮時, 鼓膜中央部の陷凹をみることより, いずれも，鼓膜張筋あるいは，両耳小骨筋によ るあのであろうと報告されている年22). 自分 で耳小骨筋収縮のできた角 ${ }^{24)}$ の報告も, 低音 で，10〜20dB の聴力低下にとどまっている. Pichler ${ }^{18)}$ の電気刺激による鐙骨筋収縮の測定 によると, 鐙骨筋, 鼓膜張筋, 両者の収縮の効 果は，5〜10dBとなっている. 中村 ${ }^{13)}$ が，ヒト で, 音響性反射収縮による中耳伝音能率の変化 を測った報告によっても，5dB以下の值であ

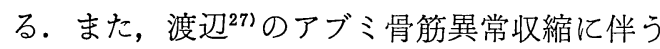
耳鳴および聴力低下， 8 例の報告をみると，大 多数は, $5 \sim 10 \mathrm{~dB}$ であり, 2 例において， $15 \mathrm{~dB}$ の気導低下をみたのみである。図 6 亿は，最む 低下の大きかった症例を記した。森満の報告も 同様である ${ }^{311}$.

以上のごとく，動物およびヒトの鐙骨筋収縮 による中耳伝音能率の低下は，5～15dB であ るというのが，てれまでの報告の結論であると 考えてよい，そして，鼓膜張筋の収縮が加わる と， $40 \mathrm{~dB}$ に達する聴力低下を示すといえる. この事実に加えて，音響性反射収縮は，10～ $100 \mathrm{msec}$ の潜伏時間があり，鐙骨筋収縮がお こるときには，すでに，強大音は，内耳へ侵入 している ${ }^{20)}$ と考元られ, 内耳の保護作用として の意義はほとんどないとするのが，乙れまでの 定説であるといえる5).

これらの事実を参照すると，著者らが今回報 告する症例のもつ意義の重大さが理解できる. すなわち，鐙骨筋の単独収縮によっておてる聴 
力低下あるいは, 内耳の保護作用が，低音部で 最大 $40 \mathrm{~dB}$ 亿達するととを示しているからであ る。乙の值は，従来報告されている鐙骨筋収縮

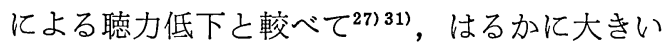
值であるといえる，しかす，ヒトで，鐙骨筋の 単独収縮によることを直接確認した初めての症 例である。

鐙骨筋の音響性反射収縮は，持続時間が短 く，それが中耳伝音能率に与える効果を，直接 正確に測定するのは難しい，したがって，本症 例のような測定を集めるととは，鐙骨筋収縮に よる伝音能率の低下を検討するのに，重要な方 法であるといえる，今回，著者らの測定したヒ トの症例は, 顔面神経麻瘦の回復過程において おこる神経の misdirection の現象が，鐙骨筋 におてったものを利用したものである．との顔 面神経麻瘏後の痙攣症之, それ伴う耳鳴の現 象は，渡辺 ${ }^{27)}$ にると，12年間に 8 例みたとい うが，著者らが，京都大学耳鼻咽喉科顔面神経 外来で, 昭和 52 年 5 月より, 昭和 53 年 6 月まで の 1 年間に観察した症例数は11例である。乙の ように顔面神経の misdirection に伴う鐙骨筋 の収縮によっておてる耳鳴は，少なからず認め られる現象であるが, その際, 聴力の変動があ るものでは，5～10dB の小範囲の変動を示すむ のが大多数である. しかし，そのなかに，聴力 闇值の大きな変動を示すすのがあり，低音域で $40 \mathrm{~dB}$ をみたあのが，本症例である，著者ら は，その他， $30 \mathrm{~dB} ， 1$ 例なごの症例も経験し ている．乙のように，顔面神経麻痺後におてる 鐙骨筋への神経の misdirection の現象は, 鐙 骨筋の単独収縮によっておてる聴力低下ないし は，過大音保護作用の大きさを，ヒトで，直接 测定しうる絶好の材料である.

最後に, 顔面神経の misdirection に伴う現 象を利用する方法の問題点にふれておきたい.

(1)神経伝達路の差一鐙骨筋の音響性反射収縮 は，末梢に伝えられた強大音による刺激が，内 耳聴神経一腹側蝸牛神経核一上オリーブ核群一 顔面神経の経路をとおり，交叉性，非交叉性の
反射路をへて, 不随意に, 鐙骨筋を収縮させる ${ }^{16)}$ わけだが, 神経の misdirection による収縮は 顔面筋への支配神経が鐙骨筋へ連絡し，乙れを 収縮させる随意収縮である。このように，両者 の間には，その神経伝達路の差異があり, 同一 の起点によって，鐙骨筋の収縮がおこるもので はない，とくに，収縮の随意性および持続時間

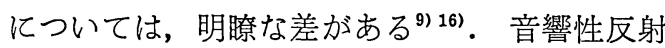
収縮の持続時間は, 約 2 秒であり, 連続刺激に 屯収縮は，低下していく．刺激音響負荷後，約 2 秒間一定の収縮が持続したあと, 徐々に減少 していく5). 一方, 神経の misdirection によ る場合は，顔面筋収縮時間と同等の間，収縮が 持続し，また，収縮の程度を随意的に変化させ ることが可能である，それゆえ，聴力低下を測 定することが可能であるわけであある.

(2)筋収縮による雑音の masking 効果一これ が実際に存在することは，同時に耳鳴を訴える ことより推測される，そして，乙の雑音が，あ る程度，マスキング効果を果していることは想 像される. しかし, 筋肉の収縮時の雑音は, $40 \mathrm{~dB}$ という大きな值を説明できるほどではな (19) と思われる.

(3)耳内筋以外の耳介周囲筋の収縮一顔面神経 の misdirection が, これらの筋に再生し，て れを収縮させる可能性を考えると, 雑音として は十分影響しうる．とくに，インピーダンス測 定の場合，これらの筋の収縮が，耳小骨筋反射 に重なって記録される可能性がある。乙れを充 分除外するよう注意する必要がある.

(4)鐙骨筋収縮のあり方の差異一本報告で示す 聴力図は, 安静時にすでに, stiffness curve を示しており，しかも， $250 \mathrm{~Hz}, 8 \mathrm{KHz}$ では, 口をとがらせた際が，むしろ聴力は，よくなっ ている. この症例の鐙骨筋の状態は, 生理的之 はいえない．筋肉の単純な収縮という現象のみ でなく，持続的収縮あるいは，緊張の亢進など の存在む予想され, これが複雑な伝音能率の変 化をきたしたと考えられる。この症例は, 同時 に顔面におこる収縮が，いわゆる顔面痤搿症で 
あるので，鐙骨筋にも，同じ現象がおてってい ることは，十分推測できる．しかし，本報告で 述べなかった他の症例，例えば外傷性顔面神経 麻痺後におてった異常共同運動（12才，男子） に伴う聴力低下 $30 \mathrm{~dB}$ では, 安静時に, 水平型 の聴力が，鐙骨筋収縮によって， stiffness curve を示した．との例では，顔面痤攣もなか った.とのように, 同じ misdirection に伴う 鐙骨筋の収縮の仕様には，差異がある．とのこ とは，音響性反射収縮との関連を考える場合， 念頭においておかねばならない。

\section{ま と め}

鐙骨筋による聴力低下（内耳の保護作用）を，顔面神経麻瘏後の misdirection の現象を材料之 して測定した，その結果，低音部において，40 dB という従来の報告より大きな值をえた。 との值 は，鐙骨筋の単独収縮による值と考えられる。

桧学教授の御校閲を深謝致します.天理よろず相談所病院耳鼻咽喉科（部長・北村溥之先生）の御援助を 深謝致します. 本論文の要旨は, 第23回日本オージオロジー学会総会（名古屋, 10月 6〜 7 日, 1978）にお いて発表した.

1) Borg. E. : Regulation of middle ear sound transmission in the nonanesthetized rabbit. Acta Physiol. Scand. $86: 175 \sim 190,1971$.

2) Frey, H. : Ueber eine besondere Form der subjectiven Geräusche. Mschr. f. Ohr. hk. Wien $70:$ 1034 1037, 1936.

3) Gerhardt, H. -J. und Wagner, H. : Zum Einfluss der Binnenohrmuskelfunktion auf die Lärmschädlichkeitsschwelle fuer kontinuierliche Toene und Geräusche beim Meerschweinchen. Archiv, klin, exper. Ohren-, Nasen-und Kehlkopfheilk. 186 : 207 215, 1966.

4) Gisselsson, L., Loefstroem, B. \& Metz, O. : The effect of succinylcholine on the middle ear muscles and on the transmission of sound through the midlle ear. Acta otolaryng. $47: 233 \sim 244,1957$.

5 ) 勝木保次編集, 生理学大系 pp. 728～731.

6）河村正三，他：鼓室小筋収縮が伝音器に及ぼす影 響闰関する実験的研究.日耳鼻 $61 ： 845 \sim 849$, 1958.

7) Kevanishvili, Z. Sh. \& Gvacharia, Z. V.: On the role of the tensor tympani muscle in sound conduction through the middle ear. Acta Otolaryng. $74: 231 \sim 239,1972$.

8) Legouix, J. P. \& Terab, S. : Experimental
文 献

study of bone conduction in ears with mechanical impairment of the ossicles. J. Acoust. Soc, Am. 3I : 1453 1457, 1959.

9) Metz, O.: Studies on the contraction of the tympanic muscles as indicated by changes in the impedance of the ear. Acta Otolaryng. $39: 397 \sim 405,1951$.

10) Moeller, A. R. : Effects of tympanic muscle activity on movement of the ear drum, Acoustic impedance and cochlear microphonics. Acta Otolaryng. 58 : 525 534, 1964.

11) Moeller, A. R. : An experimental study of the acoustic impedance of the middle ear and its transmission properties. Acta Otolaryng. $60: 129 \sim 149,1965$.

12）永井武：耳小骨筋機能简主する実験的研究. 日耳 鼻 $71: 500 \sim 534,1968$

13）中村賢二，岡本途也：人の音響性鼓室小筋反射が 中耳伝音能率に及ぼす影響に関する研究.日耳鼻 $59:$ 1933 1938, 1956

14) Neergaard, E. B., Andersen, H. C., Hansen, C. C. \& Jepsen, O.: Experimental studies on sound transmission in the human ear. III. Influence of the stapedius and tensor tympani muscles. Acta Otolaryng. Suppl. I88:280 286, 1963.

15) Nuttal, A. L. : Tympanic muscle effects on 
middle ear transfer characteristic. J. Acoust. Soc. Am. $56: 1239 \sim 1247,1974$.

16）大野吉昭：脳幹部障害における音響性アブミ骨筋 反射の分析. 日耳鼻 $81: 1356 \sim 1358,1978$.

17）恩地豊：聴器の伝音機構. 日耳鼾61回総会宿題報 告モノグラフ.

18) Pichler, von H. und Bornschein, H. : Audiometrischer Nachweis nichtakustisch ausgeloester Reflexkontraktionen der Intraauralmuskulatur. Acta Otolaryng. $48: 498 \sim 503$, 1957.

19) Reger, S. N. : Effect of middle ear muscle action on certain psycho-physical measurements. Ann. Otol. $69:$ 1179 1198, 1960.

20) Shambaugh: Surgery of the ear. 383 389, 1967.

21) Simmons, F. B. : Middle ear muscle activity at moderate sound levels. Ann. Otol. 68: 1126 2243, 1959.

22) Smith, H.D. : Audiometric effects of voluntary contractions of the tensor tympani muscle. Arch. Otolaryngol. $38: 369 \sim 372$, 1943.

23）末田卓也：家兔の耳小骨筋反射に関する実験的研 究. 日耳鼻 $74: 217 \sim 229,1971$.

24）角郁夫：音響性耳内筋反射の測定法の研究. 日耳
鼻 $65 ： 730 \sim 745,1962$.

25) Teig, E. : Differential effects of graded contraction of middle ear muscles on the Sound transmisaion of the ear. Acta Physiol. scand. $88: 382 \sim 391,1973$.

26）渡辺觔：顔面神経麻㾢の回復過程における異常現 象. とくに鐙骨筋性耳鳴について. 臨床と研究 $47: 1362 \sim 1368,1970$.

27）渡辺觔, 他：アブ こ骨異常収縮に伴う耳鳴につい て. Audiology Japan 16:81 88, 1973.

28) Wever, E. G. \& Lawrence, M.: Physiological acoustics pp. 179 196, 1954.

29) Wever, E. G. \& Vernon, J. A.: The effects of the tympanic muscle reflexes upon sound transmission. Acta otolaryng. 45 : 433 439, 1955.

30) Wiggers, H. C.: The functions of the intra-aural muscles. Am. J. Physiol. I20:771 $780,1937$.

31）森満保, 武馬成人：外傷性 Facial spasm および Stapedius spasm 症例 耳㬋 $47: 79 \sim 82$, 1975.

原稿到着：昭和53年10月11日

別刷請求先：村田 清高

于606 京都市左京区聖護院川原町53

京都大学医学部耳鼻咽喉科学教室 